\title{
Acupuncture Application in Seconder amenorrhea Obese female Patient
}

\author{
Hayriye Alp \\ Necmettin Erbakan University, GETAT CENTER, Konya, Turkey. \\ Corresponding Author: Hayriye Alp, Necmettin Erbakan University, GETAT CENTER, Konya, Turkey. \\ Received date: April 22, 2021; Accepted date: April 29, 2021; Published date: May 04,2021 \\ Citation: Hayriye Alp (2021) Acupuncture Application in Seconder amenorrhea Obese female Patient. J. Obstetrics Gynecology and Reproductive \\ Sciences 5(4) DOI:10.31579/2578-8965/072
}

Copyright: (c) 2021, Hayriye Alp, This is an open access article distributed under the Creative Commons Attribution License, which permits unrestricted use, distribution, and reproduction in any medium, provided the original work is properly cited.

\begin{abstract}
Obesity is a disease caused by excessive fat storage in the body. It is an energy balance problem. Obesity can prepare the ground for many diseases. Secondary amenorrhea is the condition of not having menstruation for 6 months. In Traditional Chinese Medicine, it is thought to be caused by Qi and blood deficiency. The 43-year-old nurse applied due to obesity, inability to have menstruation, edema and nodules in goiter. TSH was 4.25, T3 2.87, T4 $1.07 \mathrm{mU} / \mathrm{L}$. The $78.6 \mathrm{~kg} 150 \mathrm{~cm}$ tall TA was $100 / 70 \mathrm{mmHg}$. Ten sessions of acupuncture were performed. Yintan, DU-20,21, LU-9, H-7, PC-6, SI-3, ST-24,25, REN-7,9, KID-3-6, SP -6.9 uterus, zero, jerome, shen-men hunger, kidney, points were pinned with disposable acupuncture needles.

The patient, whose edema was resolved in the second session, started to have menstruation in the third session and lost $9 \mathrm{~kg}$ in total. The patient had regular periods during the 1 -year follow-up. TSH fell to $3.18 \mathrm{mU} / \mathrm{L}$.

Key words; obesity, seconder amenorhea, acupuncture.
\end{abstract}

\section{Introduction}

Obesity is observed at a rate of $25 \%$ in women, $20 \%$ in men, $22 \%$ in women and $15 \%$ in men in Europe. A study conducted in the USA also found that the prevalence of obesity, which was $22.9 \%$ in the data between 1984-1994, increased up to $30 \%$ in 1999-2000 (2). reported that they are overweight or obese (33\% overweight, $19 \%$ obese) and $10 \%$ of men are overweight or obese. Obesity also provides susceptibility to many diseases. In the USA, treatment of obesity and related diseases has an important place in general health expenses (Hill JO 1998).

In the USA, treatment of obesity and related diseases has an important place in general health expenses (Hill JO 1998).US treatment of obesity and related diseases is an important part of overall health expenditures (Hill JO, 1998).

It is thought that high intake of tasty and high-calorie foods and reduced physical activity play a role in the high rate of obesity in industrialized countries (Bray GA 1998, Campfield LA1996). Obesity increases the risk of diabetes mellitus, hypertension, ischemic heart disease, gallbladder diseases, and certain types of carcinoma. Therefore, obesity threatens public health as a chronic disease.

The Bonghan system (BS) was discovered by Bongham Kim in the 1960s. Many studies have shown that the Bonghan system has an important place in the survival of mammals. BS is a system independent of the known blood and lymphatic circulation. It is in the form of a network network that covers the entire body of mammals. In studies reported in 1962, it is stated that stem cells are stored, may be acupuncture meridians and play a role in cancer metastases. Although the first studies were carried out in
1962, studies on this subject are progressing very slowly due to the difficulties in distinguishing the system in a very small, translucent and optical way. In 2000, BS began to be re-examined with the work of Kwang-Sup Soh. It was renamed the primovascular system in 2010. Today, imaging techniques for the primovascular system continue despite the difficulties in the field (Kang KA 2016). The existence of meridians is carried out in our country by anatomists, especially with cadaver studies. If technical difficulties are overcome, evidence-based studies will increase. Here, we tried to present a case with both obese and secondary amenorrhea.

\section{Case}

The 43-year-old nurse presented with obesity, menstruation, edema and goiter nodule. She had previous cesarean section and dilatation curettage in her history. She stated that she could not menstruate due to adhesions at the obstetrician she went to, this situation disturbed her. TSH was $4.25 \mathrm{mu} / 1$, T3 was $2.87 \mathrm{mu} / 1$, T4 was $1.07 \mathrm{mu} / 1$. It was $78,6 \mathrm{~kg}$ and the TA was 100/70 mmHg. He was using levotiron. After obtaining informed consent form, 10 sessions of acupuncture was applied. Yin-tan, DU20,21, LU-9, H-7, PC-6, SI-3, ST-24,25, REN-7,9, KID-3-6, SP-6.9 in the ear uterus, zero, jerome, shen-men hunger, kidney, points were pricked with disposable acupuncture needles. $(0.25 \times 25 \mathrm{~mm}$ and $0.13 \times 20 \mathrm{~mm})$ Each session lasted 20 minutes. The patient was initially enrolled twice a week and then once a week. The patient whose edema was resolved in the 2nd session started to menstruate in the $3 \mathrm{rd}$ session and lost $9 \mathrm{~kg}$ in total. The patient had regular menstruation during the 1-year follow-up. TSH dropped to $3.18 \mathrm{mu} / \mathrm{L}$.

\section{Discussion}


They used acupuncture in combination with phytotherapy in secondary amenorrhea among rare cases in the literature. LR-3, ST-36, SP-6, ST-29 points were used in acupuncture. Turmeric $(15 \mathrm{~g})$ and fenugreek $(4 \mathrm{~g})$ seeds were used twice daily (Izzaty NR 2017) due to their estrogenic effect as a phytotherapeutic.

It is stated that in cases of secondary amenorrhea, acupuncture and turmeric (2gr), fenugreek seed (4gr) can be given until the menstrual cycle is recovered (Izzaty NR 2017). In a study, it has been shown that auricular acupuncture is both effective in reducing BMI and lowering depression scores in obese women. A randomized controlled study showed that abdominal acupuncture significantly lowers BMI, adiponectin, leptin, total cholesterol, and triglyceride levels. In the in vitro fetilization study, it was determined that acupuncture both decreases anxiety scores and increases oocyte quality and makes the endometrium suitable for pregnancy (Qian Y 2017, Sun ZG 2012). In a meta-analysis study, all types of acupuncture were evaluated and it was found that clinical pregnancy rates in in vitro fertilization treatment treated with acupuncture were higher than the control group. It has been found quite successful, especially during controlled ovarian hyperstimulation (Qian Y 2017).

\section{Conclussion}

Acupuncture can help in the treatment of such diseases by reducing anxiety, reducing obesity with hormonal balance and regulating uterine blood flow.

\section{References}

1. Bray GA (1998). Obesity: A time bomb to be defused. Lancet 1998;352:160-1.

2. Campfield LA, Smith FJ, Burn P (1996). The ob protein (leptin) pathway-a link between adipose tissue mass and central neural networks. Horm Metab Res 28:619-32.

3. Çevik C, Medikal Akupunktur. Kuban matbaacılık yayıncılık. Ankara;2.basim:21-50.

4. Hill JO, Peters JC (1998). Environmental contribution to the obesity epidemic. Science; 280:1371-4.

5. Izzaty NR.Imandiri A.Suciati (2017) .Secondary Amenorrhea therapy with acupuncture and Turmeric-Fenugreek Herbal.Journal of Vocational Health Studies.2017(1):27-31.

6. Kang KA, Maldonado C, Vodyanoy V (2016). Technical Challenges in Current Primo Vascular System Research and Potential Solutions. J Acupunct Meridian Stud. Dec;9(6):297-306.

7. Özarmağan S, Bozbora A. Obezitenin tanımı ve temel bilgiler. İçinde: Bozbora A, editör. Obesite ve tedavisi. İstanbul: Nobel; (2002).p.1-13.

8. Palou A, Serra F, Bonet ML, Pico C(2000). Obesity: Molecular bases of a multifactorial problem. Eur J Nutr 39:127-44.

9. Sun ZG, Lian F, Zhang JW2012 .[Effects of acupuncture combined Chinese materia medica for tonifying shen and soothing gan on the anxiety and depression of patients with in vitro fertilization and embryo transplantation and on the treatment outcomes]. (2012) 1023-7

10. Qian Y, Xia XR, Ochin H, Huang C, Gao C, Gao L, Cui YG, Liu JY, Meng Y(2017). Therapeutic effect of acupuncture on the outcomes of in vitro fertilization: a systematic review and metaanalysis. Arch Gynecol Obstet. 295(3):543-558. doi: 10.1007/s00404-016-4255-y. Epub 2016 Dec 19. 